\title{
肩甲舌骨筋下腹の稀なる重複例
}

\author{
九州歯科大学解 剖学教室 (指導 : 中山種秋教授) \\ 九州歯科大学口腔解剖学教室 (指導 : 山田 博教授) \\ 村上守良・六反田篤・菊池直人
}

（昭和46年 5 月24日受理）

\section{A RARE CASE OF ABNORMITY IN THE LOWER BELLY OF THE OMOHYOID MUSCLE}

\author{
By \\ Moriyoshi MURAKAMI, Atushi ROKUTANDA and Naoto KIKUCHI \\ Department of Anatomy (Director: Prof. Taneaki NAKAYAMA) \\ Department of Oral Anatomy (Director: Prof. Hiroshi YAMADA) \\ Kyushu Dental College, Kitakyushu, Japan
}

During the dissection practice for students in 1970, the following variation connecting with the muscle on the anterior neck was encountered.

The present case shows an extra variation-muscle in the Omohyoid muscle on the left side. It arises from the superior border of scapula and the superior transverse scapular ligament and goes forward and inward to be inserted anterior one-thirds on the Ist rib.

This muscle would be one of the rarest variation which had especially two belly of the omohyoid muscle.

\section{I 緒 言}

前頸部に扔ける筋の異常は特に多く, その破格の報告 例む今日まで数多く見られる。著者らは昭和 44 年度の解 剖実習において盾甲骨と第1 肋骨に付着する異常筋の一 例を見出したのでその観察所見を報告する。

\section{II 剖 查 所 見}

屍体番号 198, 昭和38年 5 月に収容された69才の男性 で死因は不明である。異常筋は左側の肩甲舌骨筋下腹と 鎖骨下筋との間にあって固有の肩甲活骨筋下腹の起始部 外側縁に接し, 起始部の巾1. $5 \mathrm{~cm}$ をむって上肩甲横靬带 および肩甲骨上縁より起始している。

起始腱は不明膫でほとんご筋質をもって起り起始後筋 巾を漸次減少しながら腕神経叢および鎖骨下動静脈の上 面を斜めに後外側より前内側方にこれと交叉して走り第 1 肋骨の胸骨端部に達し, 長さ $1.6 \mathrm{~cm}$, 巾0. $6 \mathrm{~cm}$ の停止 腱に移行し，銷骨下筋が起始する外側部で第 1 胸肋関節 より $5.5 \mathrm{~cm}$ 外側の第工肋骨の上面に停止する長三角形の
筋である，筋の全長は $8.4 \mathrm{~cm}$ ，最大筋巾は起始部であっ て1.5cm である. 支配神経は追及が不完全であるため不 明である。

$$
\text { III 考察 }
$$

舌骨下筋群の一つである肩甲舌骨筋においてもその異 常例の報告は甚だ多くおよそ次のでとく大別されてい る。すなわち

1. 全部または一部が欠如するあの.

2. 筋の全部あるいは上腹のみが重複するもの.

3.下腹が鎖骨より起始するむの（鎖骨舌骨筋 $\mathbf{M}$. cleidoh yoideus)

4. 鎖骨より起る副筋束があってとの筋に合するも の. (下腹の重複).

5．上腹が胸骨舌骨筋之瘉着するもの.

6 . 副肩甲舌骨筋.

7. 中間腱を欠ぐむの.

なよ゙であるが著者らの遭遇した異常例はその支配神経の 追及が不完全であるため銷骨下筋の破格である後鎖骨下 


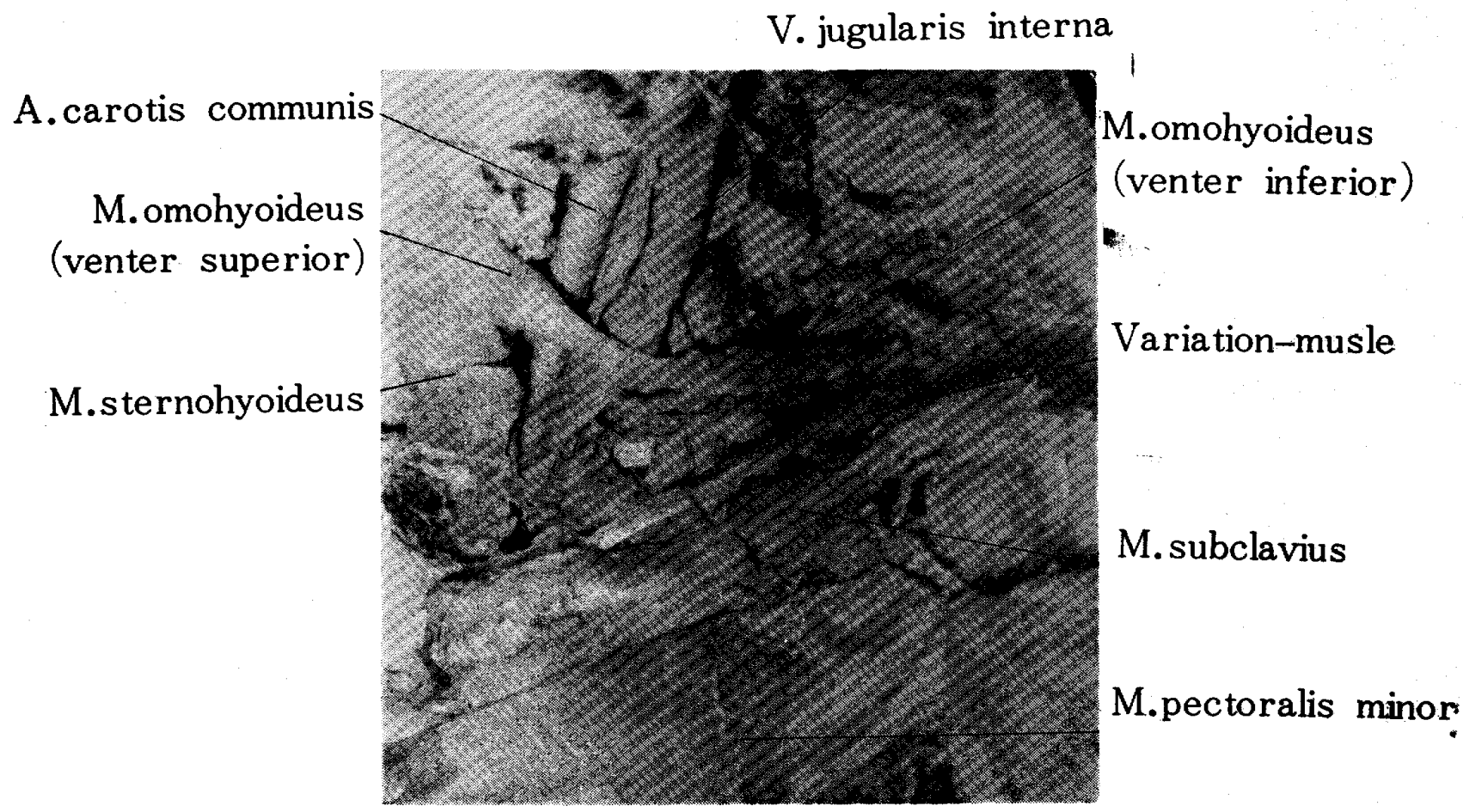

筋 M. subclavius posterior であるか否かは断定できな いが鎖骨下筋はその発育も良好で特に異常が認められな いことから肩甲舌骨筋の下腹の重複例ではないかと考元 られる。しかも該異 常筋はその出現状況 から見て佐藤 (1963・4)1,2) の報告にみるごとき非常にまれな肩甲舌 骨筋下腹の重複例であろうと思われる。そ他の頸部の 筋には特に異常は認められない。

\section{IV 結}

\section{語}

昭和44年度の解剖実習に扔いて肩甲舌骨筋下腹の異常 一例に遭遇した。すなおち左側の上肩甲横靯带および屃 甲骨上縁より起始し左第 1肋骨の胸骨端1 $1 / 3$ 部に停止する 細長い三角形の独立した異常筋で佐藤の報告した肩甲舌 骨筋下腹の非常にまれな重複例に相当するものと考えら れる。

稿を終るに当り御校閲を戴いた恩師中山種秋教授なら びに山田博教授に深謝する。

\section{$\mathrm{V}$ 文献}

1. 佐藤泰司 ; 肩甲舌骨筋下腹の重複例：解誌, 38 ( I ), 51-52, (1963).
2, 佐藤泰司, 大田善郎; 䎡甲舌骨筋の破格数例 : 日大 医誌，23 (12)，771，(1964).

3. 栃内 㛜, 青沼毅郎; 鎖骨舌骨筋 (M. cleidohyoideus）の工例之肩甲舌骨筋（M. omohyoideus）の1 異常例について：岩手医学誌， 7 (1・2)， 1-8, (1944).

4. 杤内 㛜, 加藤治良, 伴 友次, 確水 昌; 丽甲舌 骨筋の異常招上び鎖骨舌骨筋の各 1 例追加：岩手 医誌， 7， 1-2，(1944).

5. 高野武久, 高屋陸奥男, 飯塚 憲, 斗ケ沢照雄, 安 達英明; 舌骨下筋の異常に関する統計的観察 : 岩手 医大解剖学教室業績集，2，113-121，(1955).

6. 千葉郁樹, 小川隆司, 小野寺浩子, 利部輝雄, 西条 徹, 斎藤文彦, 斎藤ましろ; 胸骨舌骨筋および肩甲 舌骨筋の異常各 1 例について : 岩手医大解部学教室 業績集， 5, 87-92，(1958).

7. 山田 博, 空閑平治, 小住㫃一; 肩甲舌骨筋および胸 骨甲状筋の異常例について : 九州歯会誌, 14 (2), 70-74, (1960).

8. 山田 博, 西島 彪; 肩甲舌骨筋の稀なる破格 I例 について: 九州歯会誌， 11 (2), I-2，(1957). 